\title{
Growth and Yield of Pepper (Capsicum Annuum L.) Under Root Zone Restriction
}

\author{
Ahmet ertek ${ }^{1 *}$ and Sakine bolat ${ }^{2}$ \\ ${ }^{1}$ Department of Irrigation, Suleyman Demirel University, Turkey \\ ${ }^{2}$ Department of Irrigation and Drainage, Suleyman Demirel University, Turkey
}

Submission: October 25, 2016; Published: November 30, 2016

*Corresponding author: Ahmet ertek, Suleyman Demirel University, Graduate School of Applied and Natural Sciences, Department of Irrigation, Isparta, Turkey, Tel: 902462118566; Email: aertek25@operamail.com

\section{Abstract}

This study was carried out to determine the effects of root zone restrictions on the growth and yield of pepper. In this study, root developments of the pepper planted in three different sized pots ( $S^{1}: 6.7$ liter and height: $18 \mathrm{~cm} ; S_{2}: 11$ liter and height: $22 \mathrm{~cm} ; S^{3}: 16.5$ liter and height: $24 \mathrm{~cm}$ ) in the glass greenhouse were examined. Treatments consisted of fifteen pots per treatment, including sub-plots. Thus the total number of seedlings was $5 \times 3 \times 5$ or 75 . The experimental design was a randomized factorial design with three replications and planted Charleston pepper (Saffron F1).

The irrigation water was applied through drip irrigation systems following two different irrigation programs. In the first program $\left(I_{1}\right)$, the amount of water applied to three different sized pots at each irrigation was as much as that of the smallest pot. In the second program $\left(\mathrm{I}_{2}\right)$, irrigation water was applied based on available soil moisture consumption in pots $(6.7,11$ and 16.5 liter). In both programs, the pots were watered until field capacity when the available water in the soil fell to about $60 \%$. In this study, it was concluded that considerable water savings and high yield could be achieved through root restriction. In light of the results of the study, we recommend using soil of $18 \mathrm{~cm}$ depth and $6.7-$ liter volume irrigation application per plant in pepper cultivation when the available water level in the soil falls to about $60 \%$.

Keywords: Root zone restriction; Green pepper; Plant water consumption; Water use efficiency

\section{Introduction}

The world production of green pepper is about 24 million tons from 1.66 million ha while its production in Turkey is about 1.79 million tons from 88.000 ha Ertek et al. [1]. Pepper is included in the Capsicum genus of the Solanaceae family; perennial in warm climates, and multi-year in tropical climates it is a cultivar. Pepper plants grow best at temperatures in the range of 20 to $25^{\circ} \mathrm{C}$. Pepper plants are damaged at temperatures above $32{ }^{\circ} \mathrm{C}$ and below $5{ }^{\circ} \mathrm{C}$. Soil moisture should be at $65-70 \%$ of field capacity. Pepper plants require a large amount of water for optimal vegetative and reproductive processes. The pepper roots are very sensitive to excess water. Therefore, irrigation water required for pepper must be given adequately and without delay Koc F [2]\& GAP [3].

Pepper plants have relatively shallow root systems, and root development is approximately $60 \mathrm{~cm}$. Weekly water requirements for optimum production range from approximately 25 to $50 \mathrm{~mm}$. In the first growth period, water stress can cause yield loss by reducing plant height and shedding flowers Garton \& Bodnar [4]. Pepper is not drought tolerant due to the shallow root system. The water needs of pepper are greater, especially during periods of flowering and fruit formation. Irrigation should be conducted by furrow or drip irrigation system Berke et al. [5]. Excessive irrigation causes disease and the washing of nutrients Anonymous [6].

Pepper is one of the most widely grown vegetable plants in greenhouses. However, today it is still carried out with traditional production in greenhouse soil. The monoculture farming applied in greenhouses raises the problems outlined below;

a. The soil becomes tired

b. Soil-borne diseases 
c. Nematodes

d. The rise of groundwater

e. The formation of compacted soil layers.

To solve these problems, the greenhouse soil is washed by irrigation in summer months. In most cases, the compacted surface soil layer is loosened by tillage. Furthermore, a drainage system can be designed to remove excess water from the soil profile. However, this leads to an increase in production costs Anonymous [7].

The root rot and wilt diseases caused by soilborne pathogens are among the factors limiting pepper production Yucel et al. [8]. Many pathogens that cause diseases in pepper roots are developed in humid and warm soils and these are formed by micro-organisms that spread from the initial infection into the environment through sprinklers or furrow irrigation Ristaino JB [9], Yucel et al. [8]. One of the most important fungal diseases that limits the production of pepper in Turkey and the rest of the world and lowers productivity and quality is "Phytophthora capsici" Gocmen \& Abak [10]. Therefore, pepper plants should be grown in containers that limit the root area. Such an application might help reduce the spread of the above-mentioned diseases.

On the other hand, excessive applications of fertilizers to crops lead to nitrate and phosphate leaching and contamination of groundwater and water bodies. It is known that excessive fertilizer and chemical pesticide residues are transported to the sea from greenhouses in coastal areas. This situation is a major threat to human health when entering the sea from Mediterranean beaches because of the intensity of nearby greenhouses.

The culture plants should be grown in a controlled manner in impermeable containers in the greenhouses for the prevention of environmental contamination. In addition, drainage of these containers must also be provided. It is easier to renew the tired soil in containers. Furthermore, water and fertilizer savings and weed control can be achieved, and plant diseases can be Table 1: Some physical and chemical characteristics of soil used in the experiment.

\begin{tabular}{|c|c|c|c|c|c|c|c|c|}
\hline $\begin{array}{c}\text { Depth } \\
\mathbf{c m}\end{array}$ & $\begin{array}{c}\text { Soil Bulk } \\
\text { Density Gr/ } \\
\mathbf{C m}^{3}\end{array}$ & $\begin{array}{c}\text { Field } \\
\text { Capacity } \\
\%\end{array}$ & $\begin{array}{c}\text { Wilting } \\
\text { point } \\
\%\end{array}$ & Ph & Ecx10 ${ }^{6}$ & $\begin{array}{c}\text { Caco }^{3} \\
\mathbf{g} / \mathbf{k g}\end{array}$ & $\begin{array}{c}\text { Organic } \\
\text { Matter } \\
\mathbf{g} / \mathbf{k g}\end{array}$ & $\begin{array}{c}\text { Texture } \\
\text { \% }\end{array}$ \\
\hline $0-30$ & 1.12 & 23.9 & 13.5 & 7.8 & 378 & 292 & 16.9 & CL \\
\hline $30-60$ & 1.18 & 24.7 & 14.6 & 7.8 & 381 & 221 & 12.8 & CL \\
\hline
\end{tabular}

Fifteen seedlings were planted in fifteen pots for each treatment including replications. The study consisted of six treatments. $1-I_{1} S_{1}, 2-I_{1} S_{2}, 3-I_{1} S_{3}, 4-I_{2} S_{1}, 5-I_{2} S_{3}, 6-I_{2} S_{2}$ (I: irrigation program, $S$ : pot size). $I_{1}$ : equal application for all pots of irrigation water considering the water decrease in the smallest pot, $I_{2}$ : application for each pot of irrigation water considering prevented. Plant water stress can also be managed more easily and formation of mud on the outside areas of the containers can be better prevented. Therefore, the container depths must be determined separately for each plant species grown in greenhouses.

The conducted studies showed that the nutritional value of leafy vegetables grown in soil-less culture can be corrected by limiting of the roots Tae et al. [11]. The root system performs several key functions of plants including: support for the above ground portion, water and nutrient uptake from the soil, and assimilation of some elements essential for plant growth Rom CR [12]. Roots also synthesize certain hormones that regulate plant growth and development Shu et al. [13] , Dong et al.[14]. Damage to the root system may affect root function and growth of the whole plant. However, proper root pruning (controlled root damage) has been a widely used tool to improve nursery stock quality and subsequent growth performance in horticultural practices Hipps et al. [15]. Thus, this study was carried out to determine the effects of root zone restriction on the growth and yield of pepper plants. This study is important to eliminate the above mentioned drawbacks.

\section{Material and Methods}

The study was conducted in a greenhouse in the Research and Application Area of the Agriculture Faculty, Suleyman Demirel University. In this study, pepper seedlings were planted in three different-sized pots $\left(S_{1}: 6.7\right.$ liter and height: $18 \mathrm{~cm} ; S_{2}: 11$ liter and height: $22 \mathrm{~cm} ; S_{3}: 16.5$ liter and height: $24 \mathrm{~cm}$ ) in the greenhouse. Seedlings were planted in 15 pots including subplots for each treatment. The experiment consisted of 75 pots ( 5 x 3 x 5). Charleston pepper (Saffron F1) was planted as the plant variety. The experiment was conducted according to randomized factorial design with three replications. Saffron $F 1$ is a kind of long shelf-life, cold-resistant plant that reaches 20 to $23 \mathrm{~cm}$ in length and has light green fruits Anonymous [16]. Some physical and chemical properties of the soil used in the experiment are given in Table 1. the water decrease in each pot size. In this application, $I_{2} S_{1}$ and $I_{1} S_{1}$ treatments followed the same irrigation program. Therefore, those treatments were combined. Thus, the related values were accepted as the same for both treatments and the same values for those treatments are written in the tables. There were five pots in each sub treatment. Thus, the experiment was carried 
out with 90 pots instead of $5 \times 3 \times 5=75$ pots including sub treatments. Water was applied through drip irrigation systems and according to two different programs. In the first program, the available water in pots of three different sizes before irrigation was brought up to field capacity considering the water decrease in the smallest pot (6.7 liter). In the second program, irrigation water was applied up to field capacity considering separately the amount of water consumption for each of 11 and 16.5 liter pots. The volume of water applied in the treatments was measured by flow meter. Irrigation water was supplied from a well using a pump. The water was classified as $C_{1} S_{1}$ with a sodium risk and a low electrical conductance USSL [17].

After the seedlings were planted, they were irrigated several times until they were established. Subsequent irrigations were applied according to the prescribed programs. Treatments in both irrigation programs were watered to field capacity when the water content had dropped to about $60 \%$. The field capacity of potting soil was determined according to the principle of determination under field conditions. For this purpose, all of the pots were filled with local garden soil that was mixed with 200 mm3 manure per pot. There was $4 \mathrm{~cm}$ of space downward from the upper side of each pot. The pots of the same size were filled so as to be of equal weight. Then, a soil sample for each pot size was brought in to be air-dried. Air-dry soil was weighed together with the pot. The pots with air-dried soil were watered up to fully saturated and then covered with a plastic cover to prevent evaporation Camoglu [18], Campostrini \& Yamanishi [19]. The pots were weighed again after drainage of water leached from the bottom. Thus, available water-holding capacity of potting soil was determined by the difference of wet and dry weight. Then, ammonium nitrate $(10 \mathrm{ml})$ at flowering stage (June 6th) and potassium phosphate ( $313 \mathrm{~g}$ ) at early fruit setting (July $29^{\text {th }}$ ) were applied to each pot. The fight against disease was made according to the recommendations of the Department of Plant Protection.

Water use efficiency (WUE) was calculated using Equation (1) Howell et al.[20] \& Ertek et al.[21].

$$
W U E=(E y / E t)
$$

Where, WUE: is the water use efficiency (kg/plant/liter); Ey: the yield (kg); Et: evapotranspiration (liter).

Marketable green peppers were harvested by hand once a week and then weighed. In the marked six plants for each treatment, the number, diameter and length of fruit in each treatment were also determined by counting or measuring. Furthermore, plant height, plant cover width, flower number, and number of shedding flowers were also determined. After the marked six plants in the last harvest were removed from the soil, the root length and root dry matter weight were measured Bohm W [22] \& Baran et al. [23]. In addition, the shedding of flowers was observed from planting to harvest.

\section{Results and Discussion}

\section{Irrigation water and plant water consumption}

After seedlings were planted in pots on 16 June 2011, $400 \mathrm{ml}$ of water was applied to each pot. Before scheduled irrigations, $600 \mathrm{ml}$ of water was applied per pot on 17 and 19 June 2011. Subsequent irrigations were applied according to a determined program (Table 2).

Table 2: Amounts of irrigation water applied to treatments ( $\mathrm{ml}$ ).

\begin{tabular}{|c|c|c|c|c|c|c|}
\hline Date & $\boldsymbol{I}_{1} \boldsymbol{S}_{1}$ & $\boldsymbol{I}_{1} \boldsymbol{S}_{2}$ & $\boldsymbol{I}_{\boldsymbol{1}} \boldsymbol{S}_{3}$ & $\boldsymbol{I}_{2} \boldsymbol{S}_{1}$ & $\boldsymbol{I}_{2} \boldsymbol{S}_{2}$ & $\boldsymbol{I}_{2} \boldsymbol{S}_{3}$ \\
\hline 16.06 .2011 & 400 & 400 & 400 & 400 & 400 & 400 \\
\hline 17.01 .2011 & 600 & 600 & 600 & 600 & 600 & 600 \\
\hline 19.01 .2011 & 600 & 600 & 600 & 600 & 600 & 600 \\
\hline 21.06 .2011 & 400 & 400 & 400 & 400 & 800 & 1000 \\
\hline 23.06 .2011 & 800 & 800 & 800 & 800 & 1200 & 2000 \\
\hline 29.06 .2011 & 980 & 980 & 980 & 980 & - & - \\
\hline 03.07 .2011 & 900 & 900 & 900 & 900 & 1330 & 1950 \\
\hline 08.07 .2011 & 1060 & 1060 & 1060 & 1060 & 1520 & 1600 \\
\hline 11.07 .2011 & 910 & 910 & 910 & 910 & - & - \\
\hline 12.07 .2011 & - & - & - & - & 910 & 1970 \\
\hline 17.07 .2011 & - & - & - & - & 1490 & - \\
\hline 20.07 .2011 & 910 & 910 & 910 & 910 & 1250 & 1560 \\
\hline 24.07 .2011 & 1110 & 1110 & 1110 & 1110 & - & - \\
\hline 26.07 .2011 & - & - & - & - & 1460 & 2300 \\
\hline 29.07 .2011 & 1200 & 1200 & 1200 & 1200 & 950 & 1480 \\
\hline 03.08 .2011 & 930 & 930 & 930 & 930 & 1280 & 1730 \\
\hline 05.08 .2011 & 910 & 910 & 910 & 910 & 1610 & 2460 \\
\hline 10.08 .2011 & 1100 & 1100 & 1100 & 1100 & - & - \\
\hline 12.08 .2011 & 1100 & 1100 & 1100 & 1100 & - & - \\
\hline 16.08 .2011 & 910 & 910 & 910 & 910 & 1520 & 2230 \\
\hline 26.08 .2011 & 1300 & 1300 & 1300 & 1300 & 1600 & 2450 \\
\hline 02.09 .2011 & 1100 & 1100 & 1100 & 1100 & - & 2450 \\
\hline Total water & 17220 & 17220 & 17220 & 17220 & 18520 & 26780 \\
\hline & & & & & & \\
\hline
\end{tabular}

As can be seen from Table 2, the amounts of irrigation water applied to the treatments were; 17.220 liters per pot for treatments in the $I_{1}$ irrigation program, in $I_{2}$ program, 18.520 liters and 26.780 liters of water were applied per pot for the $S_{2}$ and $S_{3}$ treatments, respectively. In the study, the irrigation water values of treatments were also accepted as the evapotranspiration values due to controlled irrigation in pots and in the greenhouse.

\section{Yield}

The highest average yield was obtained from I1 treatments (Table 3). The highest yield was determined as $138.33 \mathrm{~g} /$ plant for $I_{1} S_{1}$ treatment with the smallest pot (6.7 liter). The pepper yield was decreased in the treatment of water applied considering the pot size. Yield values of $I_{1} S_{3}$ and $I_{2} S_{3}$ treatments consisting of the same size pots and different irrigation programs were almost 
the same. In spite of the higher water application, yield in the $I_{2} S_{2}$ treatment was less than in the $I_{1} S_{2}$ treatment even though pots in these treatments were the same size.

Table 3: Yields of treatments ( $\mathrm{g} / \mathrm{plant}$ ).

\begin{tabular}{|c|c|c|c|c|}
\hline \multirow{2}{*}{ Treatments } & \multicolumn{3}{|c|}{ Replication } & \multirow{2}{*}{ Average } \\
\cline { 2 - 4 } & A & B & C & \\
\hline I1S1 & 150.41 & 137.92 & 126.65 & 138.33 \\
\hline I1S2 & 127.81 & 116.34 & 104.87 & 116.34 \\
\hline I1S3 & 125.35 & 135.31 & 122.04 & 127.57 \\
\hline I2S1 & 150.41 & 137.92 & 126.65 & 138.33 \\
\hline I2S2 & 123.6 & 92.11 & 104.49 & 106.73 \\
\hline I2S3 & 128.16 & 128.47 & 127.84 & 128.16 \\
\hline
\end{tabular}

\section{Water-yield relationships}

When the average yields and evapotranspiration of the treatments were evaluated graphically, yields initially decreased and then increased (Figure 1). This situation shows that it is important to apply sufficient amounts of water for pepper plants. Similarly, when the average yield per pot and the pot volumes were graphically analyzed, an important polynomial relationship was determined between the yields and the pot volumes at the $1 \%$ level (Figure 2). Furthermore, when the pot volumes and the average yields per pot of the same pot sized treatments were graphically examined, the yields of the 6.7 liters, 11 liters and 16.5 liter pots were determined as $38.33 \mathrm{~g} / \mathrm{pot}, 111.54 \mathrm{~g} / \mathrm{pot}$ and $127.87 \mathrm{~g} /$ pot, respectively (Figure 3 ).

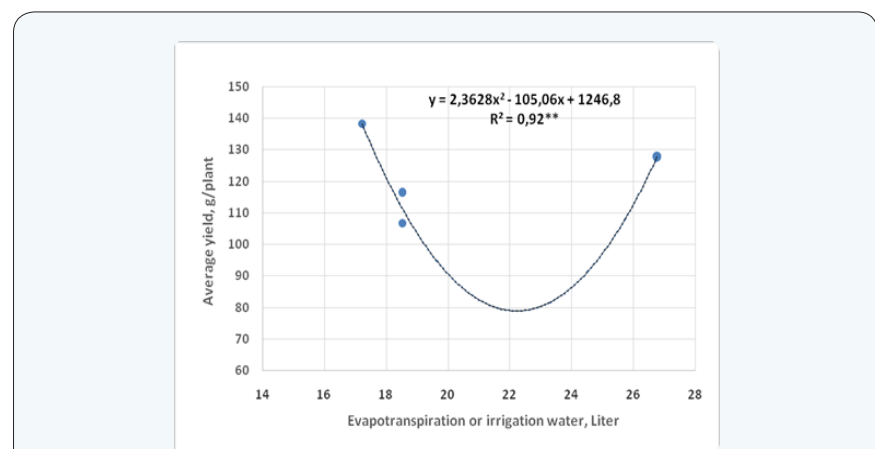

Figure 1: Relationship between plant water consumption (Et) and yield.

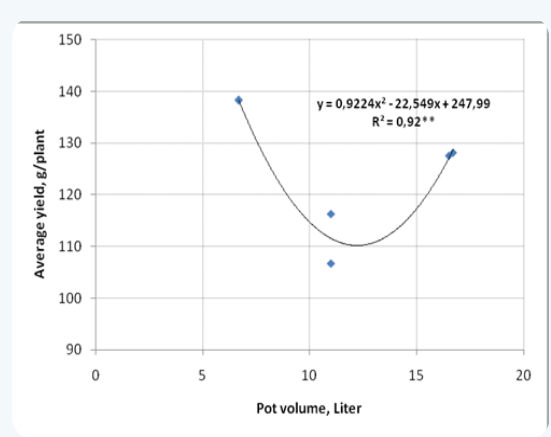

Figure 2: Relationship between pot volume (S) and yield.

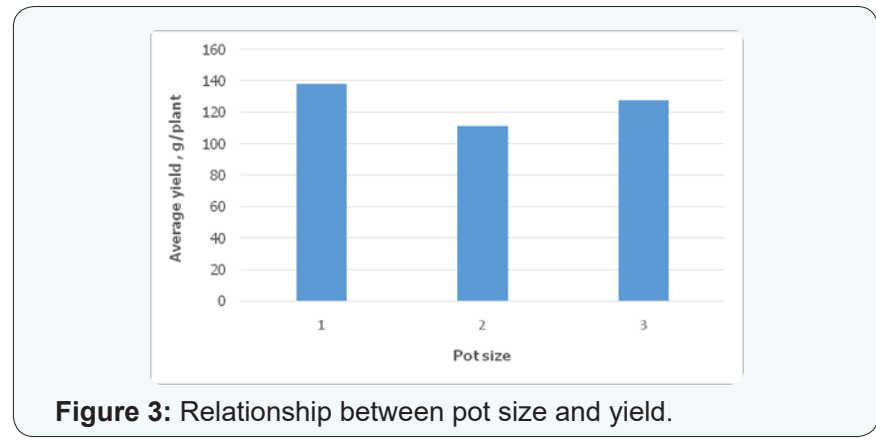

According to the results of variance analysis, while the effect of irrigation levels on yield was not important, the pot size and the irrigation level $\mathrm{x}$ pot size interactions were significant at $1 \%$ and $5 \%$ levels, respectively (Table 4 ). The maximum yield per pot was determined for the smallest pot. On the other hand, pot (S) treatments were separated into three groups according to Duncan's multiple comparison test. The highest and the smallest groups were formed from $\mathrm{S}_{1}(6.7 \mathrm{~L} \mathrm{pot})$ and $S_{2}(11 \mathrm{~L}$ pot) treatments, respectively. Consequently, the smallest pots (6.7 liter) made the greatest contribution to the pepper yield in terms of pot sizes and irrigation levels.

When other parameters are examined, effects on vegetation, plant diameter, average fruit weight and fruit length of the irrigation levels and the pot sizes were not found to be significant. The effect of the pot size on plant height and root dry weight was significant at the $5 \%$ level. However, the irrigation program did not affect those parameters. The effects of the irrigation program and pot size on fruit diameter were significant at the $1 \%$ and $0.1 \%$ levels, respectively.

Interaction of irrigation program times pot size was determined to have a significant impact at the $5 \%$ level on the fruit diameter, average fruit number per plant, plant height, root dry weight and root length. Root length of the $S_{1}$ treatment (the smallest pot) was more than other treatments. The highest root dry weight in $I_{2}$ treatment was determined in the smallest pot treatment $\left(S_{1}\right)$ and the highest root length was determined in the $S_{2}$ treatment. It can be said that yield in the smallest pot was increased because the irrigation water and nutrients applied were more easily absorbed by the plant. Furthermore, the highest yield was obtained in the smallest pot $\left(S_{1}\right)$ due to the highest level of average fruit weight per plant, fruit diameter, plant cover, plant height and the root length. Also, the highest plant root development was obtained in the $S_{1}$ treatment. The plant cover and plant height increased depending on the root growth. Thus, the pepper yield was also increased.

Without doubt, the growth of the aboveground parts of the plant plays a decisive role in the root system. Therefore, determination of the root parameter in studies related to plant growth setting stem is an important issue. Furthermore, to reveal relationships between soil and plants is also important for the monitoring of root growth Kramer PJ [24], Smucker and Aiken [25], Baran et al.[23]. 
As can be seen from Table 5, the highest water use efficiency $(W U E)$ was in the smallest pot treatment $\left(I_{1} S_{1}\right)$, followed by $I_{1} S_{3}$ and $I_{1} S_{2}$ treatments, respectively. The lowest WUE was determined at the highest water application level (I2S3). Thus, the most economical and also the highest yield was obtained from the smallest pots due to the higher WUE. This case reveals that root zone restriction is important. Campostrini and Yamanishi (2001) investigated the effects on the water use efficiency of root zone restriction in the papaya plant. They determined that WUE is increased by root zone restrictions.

The reason for the increase in yield of the small size pot is that water is directly applied to the plant roots without spreading into the environment. The water applied into greater soil volume moves laterally and deeply. Thus, it requires more energy used for water uptake through the roots of plants in greater soil volumes. In this case, the plant's energy will be used for the uptake of water and nutrients leading to a reduction in yield. Also, this can be attributed to the plants receiving water more easily due to constriction of the root zone by plant roots.

Conducted studies show that about $70 \%$ of pepper roots are spreading at $10-30 \mathrm{~cm}$ soil depth Anonymous [26]). Thus, it can be said that deeper soil layers are not necessary for the cultivation of pepper. Soil, plant and water relations usually consist of unsaturated soil conditions. While saturated flow in a soil layer occurs vertically downward, in unsaturated adjacent layers unsaturated flow may occur as a result of the capillary movement of water Kumar CP [27].

The retention of water in a soil depends on the capillary force and the molecular attraction of the particles. Capillarity is a function of the natural forces of adhesion and cohesion. Adhesion is the attraction between two molecules of different substances. Water is kept by the electrostatic forces found in the inner and outer surfaces of the soil particles. The layers consisting of several water molecules strongly surround the soil particles with strong adhesive forces. This water is called the adhesion water. Adhesion water only moves to a small extent, therefore it cannot be useful to plants. The attraction of water molecules to each other is termed cohesion. Water retained in soil because of cohesive forces is called cohesion water. Because of increased movement of water molecules in the case of cohesion, approximately $70 \%$ of the water is used by plants. Movement of water in soil saturated with water is towards the dry or unsaturated soil. Absorption of water by plant roots also allows the movement of water Munsuz N [28], 0 Geen [29].

The first flowering date and the number of flowers and the number of shed flowers in treatments during the growing season are shown in Table 6. According to the values obtained, the number of first flower nodes in the smallest pots was more than in the others. This also increased early yield in the small pots. The early yield is more economic for farmers. Therefore, the $I_{1} S_{1}$ treatment is important in pepper cultivation.
The number of average shed flowers per pot was greater in $I_{1} S_{2}$ treatment. Although there was more flower shedding in I1 treatments, yields were higher than 12 treatments. This situation can be attributed to more flowering due to more effective absorbtion of water and fertilizer by plants with restricted root zones. If the shedding of flowers can be prevented by other cultivation measures, higher yields can be obtained in the smallest pots. Furthermore, because the evaporation surface decreases in the smaller pots, the plant water consumption through transpiration will be more. This situation will enable increases in yield.

Pepper plants have a high demand for water and nutrients and are particularly sensitive to water stress during the establishment period and fruit setting. High levels of irrigation are often applied in order to maximize yields. However, field observations suggest that excessive irrigation may negatively affect bell pepper plants Diaz-Perez [30]. Plant water status may equilibrate with the wettest part of the root zone, which could contribute to the maintenance of plant water balance as suggested by Hsiao [31]. Our study revealed the more effective use of water by the plant roots in small pots.

Container size can affect the growth and development of bedding plants. Greenhouse crops are grown in many types of containers, with volumes that vary widely. Since container volume affects the amount of available water and nutrients, it can have pronounced effects on the growth of plants. Most research on the effects of container volume on growth and development has focused on vegetables and trees Van Iersel [32].

Van Iersel [32] made a study of salvia (Salvia splendens) grown in different container sizes and stated that it was decreased by the time of first flower opening with the decrease of container size. In addition, based on previous studies, researchers have stated that depending on plant species root restriction can affect the first flowering time. Some researchers have stated that the flowering of bell pepper, cotton and starfruit plants can be delayed by root restriction Carmi [33], Ismail and Noor [34] NeSmith, et al. [35], Ruff et al. [36]. They stated that there can be a delay in fruit maturation and flowering in tomato by root restriction. NeSmith et al. [37] stated that root restriction resulting from small containers did not have an influence on duration of flowering or time to anthesis in summer squash. The above mentioned literature supports the suggestion made in this study that root restriction will not cause a significant reduction in yield in vegetable crops.

\section{Conclusion}

Farming with root zone restriction in containers will solve the problem of soil-borne pests and diseases and increase the yield and quality. In addition, more efficient use of water and fertilizer and more controlled production is also very important in terms of less labor, the conservation of the soil and water resources and the prevention of environmental pollution. The 
findings of this study show that significant water savings as well as higher yields can be achieved by root zone restriction. Thus, it is recommended to use soil of $18 \mathrm{~cm}$ depth and 6.7-liter volume per plant in pepper cultivation. A review of the literature found very few studies on the root limitation issue. Therefore, more research should be conducted into this subject.

\section{References}

1. Ertek A, Sensoy S, Gedik I, Kucukyumuk C (2007) Irrigation Scheduling for Green Pepper Grown in Field Conditions by Using Class-A Pan Evaporation Values. American-Eurasian J Agric \& Environ Sci 2(4): 349-358.

2. Koc F (2008) Farklı Organik Gübrelerin Domates ve Biber Bitkisinin Gelişimi ile Beslenmesine Etkisi (in Turkish). Ankara Univ Fen Bil Enst Toprak Anabilim Dalı, Yüksek Lisans Tezi, 175 s.

3. GAP (2011) Biber Tarımı TC Kalkınma Bakanlığı GAP Bölge Kalkınma İdaresi Başkanlığı.

4. Garton RW, Bodnar J (1991) Pepper production. Agriculture and Rural Division. Original Factsheet, 257s.

5. Berke T, Black LL, Talekar NS, Wang JF, Green SK, et al. (1999) Suggested cultural practices for chili pepper. International cooperators2 guide, AVRDC pub $483 \mathrm{~s}$.

6. Anonymous (2011a) Açık Tarlalarda Biber Yetiştiriciliği (in Turkish).

7. Anonymous (2011b) Serada Biber Yetiştiriciliği (in Turkish).

8. Yucel S, Gunactı H, Sezen SM (2013) Salçalık Biber Yetiştiriciliğinde Farklı Sulama Yöntemlerinin Toprak Kökenli Hastalık Çıkışı ve Verime etkileri (in Turkish). Derim 30(2): 11-21.

9. Ristaino JB (2003) Influence of Rainfall, Drip Irrigation and Inoculum Density on the Development of Phytophthora Root and Crown Rot Epidemics and Yield in Bell Pepper(1991). Phytopathology 81(8): 922929.

10. Gocmen M, Abak K (2006) F1 Hibrit Biber Çeşitlerinin Phytophthora Capsici'ye Karşı Tepkilerinin Belirlenmesi (in Turkish). Akdeniz Üniv Zir Fak Derg 19(2): 199-205.

11. Tae CS, Han CR, Hyung KY, Changhoo C (2013) Effect of root zone restriction on the growth response and phytonutrients contents of leafy vegetables grown in a DFT system. Korea Journal of Horticulture Science and Technology 28(3): 415-422.

12. Rom CR (1996) Tree fruit physiology: Growth and development. Maib, Karen M, et al. (Eds.), Good Fruit Grower, Yakima, Washington, Australia, p. 53-67.

13. Ruff MS, Krizek DT, Mirecki RM, Inouye DW (1987) Restricted root zone volume: Influence on growth and development of tomato. Journal of the American Society for Horticulture science 112(5): 736-739.

14. Dong S, Cheng L, Scagel CF, Fuchigami LH (2003) Root damage affects nitrogen uptake and growth of young Fuji/M.26 apple trees. Journal of Horticultural Science \& Biotechnology 78 (3): 410-415.

15. Hipps NA, Higgs KH, Collard LG (1996) The effect of irrigation and root pruning on the growth of sycamore (Acer pseudoplatanus) seedlings in nursery beds and after transplantation. Journal of Horticultural Science 71(5): 819-828.

16. Anonymous (2014a).

17. USSL (1954) Diagnosis and Improvement of Salina and Alkali Soils. Agriculture Handbook No: 60, USA, pp. 160.
18. Camoglu G (2013) the effects of water stress on evapotranspiration and leaf temperatures of two olive cultivars. Zemdirbyste Agriculture 100(1): 91-98.

19. Campostrini E, Yamanishi OK (2001) Influence of mechanical root restriction on gas-exchange of four papaya genotypes. Rev Bras Fisiol Veg 13(2): 129-138.

20. Howell TA, Cuenca RH, Solomon KH (1990) Crop yield response. Management of farm irrigation systems. Hoffman et al. (Eds.), ASAE 312, Washington, USA, p. 19.

21. Ertek A, Sensoy S, Gedik I, Kucukyumuk C (2007) Irrigation Scheduling for Green Pepper Grown in Field Conditions by Using Class-A Pan Evaporation Values. American-Eurasian J Agric \& Environ Sci 2(4): 349-358.

22. Bohm W (1979) Methods of Studying Root Systems. Ecological Studies 33.

23. Baran A, Caycı G, Ozturk l, Ataman HSY, Ozkan I (1996) Farklı ortamlarda yetiştirilen biber bitkisi (Capsicum annuum L.) nin kök parametrelerindeki değișimler (in Turkish). Tarım Bilimleri Dergisi 2(2): 1-4.

24. Kramer PJ (1988) Changing concepts regarding plant water relations. Plant Cell Environment 11(7): 565-568.

25. Smucker MA, Aiken RJ (1992) Dynamic root responses to water deficits. Soil Science 154(4).

26. Anonymous (2014b) Biber Yetiştiriciliği (in Turkish).

27. Kumar CP (2014) Modelling of unsaturated flow. p 1-10.

28. Munsuz N (1982) Toprak-Su ilişkileri. Ankara Üniversitesi Ziraat Fakültesi yayınları: 798, Ders Kitabı: 221, Ankara.26

- Geen AT (2012) Soil, Water Dynamics. Nature Education Knowledge 3(6): 12.

29. Diaz-Perez JC (2009) Drip irrigation levels affect plant growth and fruit yield of bell pepper. Proceedings of the 2009 Georgia Water Resources Conference, University of Georgia, Georgia, p. 1-2.

30. Hsiao TC (1991) Plant-atmosphere interaction, evapotranspiration and irrigation scheduling. Acta Horticulture 278.

31. Van Iersel MV (1997) Root Restriction Effects on Growth and Development of Salvia (Salvia splendens). Hort Science 32 (7): 11861190.

32. Carmi A (1986) Effects of root zone volume and plant density on the vegetative and reproductive development of cotton. Field Crops Res 13(1): 25-32.

33. Ismail MR, Noor KM (1996) Growth, water relations and physiological processes of starfruit plants under root growth restriction. Scientia Hort 66(1-2): 51-58.

34. NeSmith DS, Bridges DC, Barbour JC (1992) Bell pepper responses to root restriction. Journal of Plant Nutrition 15(12): 2763-2776.

35. Ruff MS, Krizek DT, Mirecki RM, Inouye DW (1987) Restricted root zone volume: Influence on growth and development of tomato. Journal of the American Society for Horticulture science. 112(5): 736-739.

36. NeSmith DS (1993) Influence of root restriction on two cultivars of summer squash (Cucurbita pepo L.) Journal of Plant Nutrition 16(3): 421-431. 
Your next submission with JuniperPublishers will reach you the below assets

- Quality Editorial service

- Swift Peer Review

- Reprints availability

- E-prints Service

- Manuscript Podcast for convenient understanding

- Global attainment for your research

- Manuscript accessibility in different formats ( Pdf, E-pub, Full Text, audio)

- Unceasing customer service

Track the below URL for one-step submission http://juniperpublishers.com/online-submission.php 